\title{
Ecological Management Accounting-Taking into Account Sustainability, Does Accounting Have Far to Travel?
}

\author{
Chris A. Kelsall ${ }^{\mathbb{D}}$ \\ Lancashire School of Business and Enterprise, University of Central Lancashire, Preston PR1 2HE, UK; \\ cakelsall@uclan.ac.uk; Tel.: +44-(0)-1772-894-548
}

Received: 2 October 2020; Accepted: 23 October 2020; Published: 25 October 2020

\begin{abstract}
Concerns regarding the development of environmental accounting have been around for decades. This work is an update to some of the previous questions around the development of ecological accounting to see how this has changed over the last two decades. The work is based on a systematic review of two journal articles from separate accounting journals. The two articles are by widely published academics and are formative ecological management accounting papers highlighting issues since 2000. The analysis includes a comparative review of the two articles, a review of successive articles in the journals, and a citation analysis. The first general finding is around the complex and confusing terminology that is still used, exemplified in the amorphous term sustainability. Specific findings from the paper analysis include ecological management accounting requires a fundamental change to organization management, different values exploring relationships such as material flows, inclusive of the living and physical world, with a longer time horizon, and a centrality of external factors. Due to these challenges, ecological management accounting is presently not used as a research category and therefore is an un-developed research domain. Environmental accounting is a more commonly used synonym for ecological accounting, though this term is distinct and does not cover many of the ecological challenges. Under this research area, there have more recently been attempts to bridge the difficult macro (planetary) and micro (organization) environmental challenge. Concepts such as Accounting for the Management of Ecosystems and Material Flow Cost Accounting are areas of research seen as offering future opportunities to develop into a more ecological management accounting framework, though this will ultimately require research in ecological management accounting based on a multi-disciplinary approach.
\end{abstract}

Keywords: accounting; ecological; environmental; sustainable development

\section{Introduction}

This research sets out to explore how far ecological management accounting has developed since 2000 [1]. The business community over the last two decades has developed an interest in external factors, broadly termed as social and environmental concerns. The development of frameworks such as Integrated Reporting and narrative reporting guidelines have increased the reporting on and accountability of organizations to these issues. This paper is exploring how far this move has developed in terms of ecological management accounting over the last two decades. This work starts with a challenge to the concept of environmentally concerned businesses, drawing a wider ecological view of the issues and business concerns [1]. In doing so, one central issue is whether the business community can carry on with small changes and become ecological enterprises, or whether this requires a significant and fundamental change in organizations to shift the focus to achieve a more ecological balance. This can be seen as a move towards relationships and away from the discrete 
object system that underpins much of accounting theory [1]. More recently there have been additions to this discussion with a subsequent call as to the current state of affairs with sustainability, and the macro picture of ecological catastrophe that may be around the corner [2]. The prevailing notion is that businesses have argued all is fine and, that under the term 'sustainable business', they are tackling environmental concerns. This argument can be developed, and several models used to explore the permutations [3]. There are some different ways that the environmental issues can be resolved. In one case, these have developed into three different approaches, defined as technocentrism; sustaincentrism, and envirocentrism [3]. The model may be seen either as transitional from one stage to another or as separate silos; either supportive of and or in contrast to the current business view. Much of the academic accounting research work is within the boundaries of Social and Environmental Accounting (SEA) and sustainability. So, an important sub-question is how these do (or do not) cross into the boundary of what can be defined as ecological accounting? In the end, is this a reflection on a business and whether becoming more environmental and sustainable is leading to an ecological business model and or is this something else? This paper is, in effect, updating this discussion to explore how far the notion of ecological management accounting has come over the last twenty years [1]. It is important to stress that terms such as environmental and sustainability have become commonly used and synonymous in the business community. Previous discussions on ecological accounting have highlighted the care that must be taken to ensure these terms are not conflated in and with the ecological term and concepts and in exploring this to highlight where there are differences and how this is moving forward the discussion and debate on ecological business [1].

The research process supporting this discussion is threefold: first of all, after establishing the current social and environmental academic accounting field there is a comparative review of two original papers [1,2]; there then follows a systematic review of the literature in the two accounting journals connected with the papers: [1]—Critical Perspectives on Accounting (CPA); [2]—Social and Environmental Accountability Journal (SEAJ). This is, in effect, more of a meta-analysis of articles from these two journals over the last twenty years. Both have covered social and environmental concerns in the accounting field over the 20 years but to what extent and specifically can this be connected back to the ecological debate? The final research process is a citation analysis of the papers and articles citing the papers that are the most highly cited articles—in effect exploring the most important (widely used and referred to) articles and implicit debates from the formative papers [1,2]. This provides a partial academic accountant's view of the development of the environmental debate over this time.

There have been general systematic reviews of journals [4] but these have in essence looked at the range of topics that have developed over time periods. This work is focused on the following two journals that published important articles on environmental accounting. The difference in this work is that it has a specific focus on one topic area, environmental accounting. The first challenge in this work concerning the terminology and use of synonyms in 'environmental accounting' is tackled in the following section.

\section{Ecological Management Accounting}

\subsection{Where Did This Come From?}

Issues that can be defined as social and environmental concerns have been around in the accounting community, especially the academic accounting community, for decades. From the academic community, in the first edition of the journal Accounting, Organizations and Society in 1976 there is an article titled 'The corporate environmental accounting system: A management tool for fighting environmental degradation' [5]. In terms of the professional accounting community, the Association of Chartered Certified Accountants (ACCA) supported the publication of Greening of accountancy in 1990 [6] and have latterly explained environmental management accounting to members and students [7]. Further markers of the length of time environmental issues have concerned accountants include a trumpeted silver anniversary in 1997 and therefore 25 years of social and 
environmental accounting [8] — taking it back to the early 1980s. The 1993 book Accounting for the Environment is also a seminal work in this area [9]. There is a history of SEA, though the boundaries of the review are difficult to pin down, especially in relation to particular terms such as corporate responsibility and sustainability and accounting. This creates concern over the clarity and focus of the research. The concept of sustainability accounting has, on one hand, been seen as an important way of accounting for the social, environmental, and ecological impacts of firms. It has at the same time been challenged as being a buzzword, an umbrella term, an overarching measurement system, or a pragmatic stakeholder engagement process [10]. This complexity has been one of the issues in the development of this concept and process in accounting, like a jigsaw puzzle of seeing the parts and not the whole. These specific inter-relationships between the economic, social, and environmental have been spelt out The Triple Bottom Line is an attempt to try and incorporate social and environmental concerns into the accounting valuation system and has struggled to bridge the concept of environmental and social values with a measurement figure [11]. The basic premise of trying to co-create social and environmental values aligned to the economic values has proved difficult.

\subsection{Where Does Ecological Management Accounting Spring From?}

This paper is researching specifically 'ecological' management accounting, with a clearer focus on environmental concerns. The research paper starts with two original journal articles [1,2].

There is a view that there are two stages to the move to ecological accounting, firstly a move from economics to environmental economics [1]. This is likely to be where a business is currently operating, taking into account environmental concerns in the business model but treating them as separate issues rather than as a holistic approach [1] (p. 296). A movement towards an eco-balance where there are the physical flows of resources, raw materials etcetera is realistic [1] (p. 297). Ultimately accounting is seen as having to change due to changes in the environment it operates in, this leads to step 2, change-from environmental economics to economic ecology. A move to putting the focus on the integration of the living and physical environment. To do this accounting will need to change to an 'age of other values' [1] (p. 300) and would need to move away from just a money measurement process, to one that is also 'hailaz' (whole, complete, interconnected) [1] p. 302). This results in the creation of a cloverleaf model which interrelates different aspects including the resource flow and impact into the organizational analysis model [1] (p. 304).

There is a further exploration of how environmental management accounting could help organizations move towards more sustainable development [2]. The paper highlights some of the current challenges in bridging the concept of planetary boundaries with environmental management accounting [2]. The biggest challenge is trying to link macro issues such as planetary boundaries to organization concepts. This is developed into nine planetary areas, and when related to environmental management accounting research and concepts, Environmental Management Accounting (EMA) has been an example linked using material flow cost accounting [2] (p. 21) [12]. These are seen as intermediate issues that are close to the business operations. EMA is held as not addressing planetary issues but focusing on environmental topics [2] (p. 25). The intention to use science-based targets from the planetary level to be able to connect to measures firms can relate to. This stage can be aligned to environmental economic concepts (step 1) [1] and clearly, there are challenges in achieving this step which does not seem to have been bridged over the last two decades. The view is that this step needs to be achieved before considering the idea of economic ecology.

\subsection{Other Areas of Discussion}

This brief section additionally highlights important ecological and or EMA discussions and the influence on environmental accounting development.

The growth of interest in environmental accounting has been rapid, though much of this is constrained by traditional approaches (managerialism) which pushes the organization central to the debate rather than the environment [13]. This organization-centric view is developed even at this time 
as an impediment to sustainable development. EMA is connected to sustainable development, to meet this, it needs to ensure that current and future generations have achieved eco-justice, eco-efficiency, and eco-effectiveness [11] (p. 6). This concern over the terminology used in the debates is highlighted in a discussion on the development of SEA [14]. This systematic analysis of the development of SEA in the journal CPA illustrates the complexity and interrelation between social and environmental issues. Where environmental concerns are developed separately, they cover issues such as limited environmental reporting at the start of the period (the 1990s), fundamental change in environmentalism to escape managerial shackles, the tension with and need to look beyond financial accounting in environmental reporting, the problems in environmental measures and emissions trading systems.

Environmental accounting has become more important due to stakeholder concerns and pressure and the rise in the cost of environmental issues [9]. Stakeholders attributed to organizations have become more vocal and campaigning on environmental concerns, including government agencies and pressure groups such as Extinction Rebellion [15]. Environmental costs have increased beyond what would have been seen as 'clean up costs' in the past, to include the impact on communities and future generations [16] (see the example of the BP $\$ 60$ billion costs of the Gulf of Mexico oil spill disaster).

\section{Materials and Methods}

There are two stages to the data analysis phase of this paper. Data creation is firstly in the form of a systematic literature review of two specific accounting journals. The second stage is a citation analysis of related articles.

In terms of a systematic literature review - this can be described as a meta-analysis [4] although guidance from the systematic literature review process informs much of the approach to this work [17]. This work is not exploring a range of literature and data sets, but initially, the whole of two journal article title data sets in the time period analyzed. Systematic literature review guidance has suggested 6 key stages to the process: 1 . Define the research question; 2 . Characteristics of primary research; 3. Baseline sample; 4 . Synthesis sample; 5 . Synthesis literature; 6 . Report the results [18]. The research question is how has ecological management accounting been developed in the academic accounting field since 2000 [1]? In terms of stages 2-4, they are to be developed in this section, with the synthesis covered in the analysis section of this paper, and the report being central to the discussion and conclusion sections. This analysis builds on previous meta-analysis approaches [4] but adds to this in terms of exploring one concept-environmental accounting; comparatively exploring how the articles in two distinct journals show this as having developed over time; meanwhile, also taking account of the important (most cited) developments of the original papers.

An approach to exploring how ecological management accounting research has developed is to carry out a systematic review of the journals where the influential papers were published [1,2]. This provides an idea of the changes and direction of research in EMA. This work is providing the first stage to future research work, covering a wider range of journals and a more in-depth systematic review process of the EMA research development. This work will therefore be based on the views (as shown through the publications) of the academic accounting community. The academic community should provide a picture of where the accounting community is moving in terms of ecological management accounting. The two journals that form the basis of this analysis were chosen as they were the publishers of the original papers in this work, and so can provide a narrative of the development of EMA over the subsequent time period. Focusing on the two journals allows a full analysis of all the articles in the two journals during this period. The two journals cannot be held as a representative sample for the whole of the accounting academic field, and this will be reflected in the discussion section to this work. Even a wider systematic literature review of accounting journals does not contemplate other data sources and publications from within the accounting field, such as professional body magazines, practitioner reports. The period under review is from 2000 until the present [1]. According to the Chartered Association of Business Schools (CABS) Academic Journal Guide 2018 [19], the following are the number of accounting journals in the defined categorizations of quality—the highest quality 
standard being $4^{*}$, with lower-ranked journals 1 . CPA [1] is from within the 3 classification and SEAJ [2] from the 1 classification. Both authors are well-established professors in accounting and have published extensively in a range of accounting journals on issues around accounting and the environment (Table 1).

Table 1. Accounting journal rankings-Association of Business Schools (ABS) journal rankings 2018.

\begin{tabular}{ccccc}
\hline Ranking & $\mathbf{4}^{*}(\mathbf{4})$ & $\mathbf{3}$ & $\mathbf{2}$ & $\mathbf{1}$ \\
\hline Accounting Journals & $4(2)$ & 21 & 34 & 27 \\
\hline
\end{tabular}

The first journal to be reviewed is Critical Perspective on Accounting (CPA) as this was the publisher of [1]. Following this approach, Social and Environmental Accountability Journal (SEAJ) was the publisher of [2]. The two journals have been reviewed in terms of the articles published over the period 2000-2020, with the focus on those relating to SEA. This sample allows a review on a temporal basis of changes in the articles included in the journals. Using the International Federation of Accountants (IFAC) definition of Environmental Accounting (2005) [20], Table 2 shows the development of the environmental management accounting concept.

Table 2. The development of Environmental Management Accounting—concepts (based on IFAC, 2005).

\begin{tabular}{|c|c|c|c|c|}
\hline \multirow[t]{6}{*}{ Root Terms } & Root Terms & \multicolumn{3}{|c|}{ Derivative Terms } \\
\hline & \multicolumn{4}{|l|}{$\begin{array}{l}\text { Environmental Financial } \\
\text { Accounting }\end{array}$} \\
\hline & & Physical & $\begin{array}{l}\text { Material Flow Cost } \\
\text { Accounting }\end{array}$ & \\
\hline & $\begin{array}{c}\text { Environmental Management } \\
\text { Accounting }\end{array}$ & Monetary & $\begin{array}{c}\text { Cost } \\
\text { Waste cost } \\
\text { Prevention cost } \\
\text { Research and } \\
\text { Development Cost } \\
\text { Less Tangible Cost }\end{array}$ & $\begin{array}{l}\text { Product } \\
\text { Non-product }\end{array}$ \\
\hline & \multicolumn{4}{|l|}{ Full Cost Accounting } \\
\hline & \multicolumn{4}{|l|}{ Natural Resource Accounting } \\
\hline \multirow{2}{*}{$\begin{array}{l}\text { Environmental } \\
\text { Accounting }\end{array}$} & National Accounting & & & \\
\hline & Sustainability Accounting & & & \\
\hline
\end{tabular}

From these derivative words, root words have been identified that form the basis of the 'keyword' analysis of the article titles. The root words identified are environment; natural; sustainable. Also taken from the further breakdown of environmental management accounting are material flow cost accounting; waste cost. Other terms were also included which could be derived from the root words, and or could be considered as covering environmental issues including air; pollution; climate; biodiversity; water; energy; ecology; green. Other relevant terms used in the reporting process include Corporate Social Responsibility (CSR and/or CR); carbon reporting; Global Reporting Initiative (GRI) and Integrated Reporting. These terms are used to help isolate article titles that have an environmental angle to them. Using these terms would have highlighted the two original articles and are used as a first-order analysis of the sample journal articles over the period 2000 to 2020.

In terms of the period under review, this has been further refined to allow a comparative temporal analysis in terms of the changes over the period. It is useful to include an awareness of the external factors that influence the accounting community and particularly the academic group interested in SEA. The following table provides a snapshot of environmental events over time which provides some context to the changes and pressure on the environmental accounting research community (Table 3 ). 
Table 3. Brief-time plan of issues 2000-10 and 2011-2020.

\begin{tabular}{|c|c|c|c|c|c|c|c|}
\hline \multirow[t]{2}{*}{ Time Phases } & \multicolumn{4}{|c|}{ Phase 1} & \multicolumn{3}{|c|}{ Phase 2} \\
\hline & 1990 & 1992 & 1993 & 2010 & 2014 & 2015-16 & 2020 \\
\hline Events & $\begin{array}{l}\text { Critical } \\
\text { Perspectives } \\
\text { on } \\
\text { Accounting } \\
\text { (CPA) } \\
\text { founded }\end{array}$ & $\begin{array}{l}\text { United Nations } \\
\text { Framework for } \\
\text { Climate Change } \\
\text { (UNFCC)-Kyoto } \\
\text { protocol } \\
\text { concluded } 1997\end{array}$ & $\begin{array}{c}\text { Social and } \\
\text { Environmental } \\
\text { Accountability } \\
\text { Journal (SEAJ) } \\
\text { founded }\end{array}$ & $\begin{array}{c}\text { BP } \\
\text { Deepwater } \\
\text { Horizon } \\
\text { disaster }\end{array}$ & $\begin{array}{l}\text { Flint } \\
\text { water } \\
\text { crisis }\end{array}$ & $\begin{array}{l}\text { UNFCC- } \\
\text { Paris } \\
\text { agreement; } \\
\text { SDGs } \\
\text { adopted }\end{array}$ & $\begin{array}{l}\text { Global } \\
\text { pandemic- } \\
\text { covid 19; } \\
\text { COP 26 } \\
\text { delayed } \\
\text { until 2021. }\end{array}$ \\
\hline
\end{tabular}

Note: Colours split the time period in half, pre and post 2010 (2000-2010 light colour; 2011-2020 dark colour).

The period is to be split into two sections, from 2000-2010 - phase 1 and 2011-2020—phase 2. This provides a brief overview of the environmental events and period of the journals. Due to the nature of academic research, there will be time delays in the influence of any external events and the outputs in the journals due to the writing, review, and publication requirements of article writing. So, direct correlations between the events and discussions need to take this into account.

\section{Results}

The following section sets out the main aims of the journals, CPA and SEAJ, an overview of the most cited articles on environmentally related issues, and then the most cited (including outside of these two journals) academic articles referring to the formative papers [1,2].

In terms of the journals that published the central articles, the aims and scopes are identified in Table 4 of CPA, and SEAJ is in Table 4.

Table 4. The aims and objectives of the two journals.

\begin{tabular}{|c|c|}
\hline Critical Perspectives on Accounting (CPA) & Social and Environmental Accountability Journal (SEAJ) \\
\hline $\begin{array}{l}\text { 'to provide a forum for the growing number of } \\
\text { accounting researchers and practitioners who realize } \\
\text { that conventional theory and practice are ill-suited to } \\
\text { the challenges of the modern environment and that } \\
\text { accounting practices and corporate behaviour are } \\
\text { inextricably connected with many allocative, } \\
\text { distributive, social, and ecological problems of our era. } \\
\text { From such concerns, new literature is emerging that } \\
\text { seeks to reformulate corporate, social, and political } \\
\text { activity, and the theoretical and practical means by } \\
\text { which we apprehend and affect that activity.' [21] } \\
\text { Note: accounting in bold in original. }\end{array}$ & $\begin{array}{c}\text { 'committed to the creation of new academic literature in the } \\
\text { broad field of social, environmental, and sustainable } \\
\text { development accounting, accountability, reporting, } \\
\text { and auditing. The Journal provides a forum for a wide } \\
\text { range of different forms of academic and academic-related } \\
\text { communications whose aim is to balance honesty and } \\
\text { scholarly rigour with directness, clarity, policy-relevance, } \\
\text { and novelty.' [22] } \\
\text { Note: new Italicized in original. }\end{array}$ \\
\hline
\end{tabular}

The journals are distinct in the aims and scope, with CPA having a broader view, which can be identified as a social concern and focus in terms of accounting, whilst SEAJ is directed towards the environmental and ecological concerns. The two journals represent two distinct accounting groups-CPA has a wider perspective, and in this work can be seen more as a general academic accounting journal. On the other hand, SEAJ is focused on environmental accounting concerns and can be seen therefore as an ecological/environmental academic accounting journal. The differences between the journals will result in a variation in environmental article development, with SEAJ showing changes in the focus of environmentally relevant research papers; CPA will be the same but this will also enable a weighting in terms of the overall interest (relevant articles) in a journal not specifically set up to review environmental concerns and accounting.

The data set consists of all journal articles published in CPA and SEAJ between 2000 and 2020 (current-August 2020). The details are in Table 5. 
Table 5. Total articles and issues-CPA and SEAJ, 2000-2020 (August).

\begin{tabular}{cccccc}
\hline Time & Issues and Articles & CPA & \% of Total & SEAJ & \% of Total \\
\hline \multirow{2}{*}{$\begin{array}{c}2000-2020 \\
(\text { Total) }\end{array}$} & Issues & 147 & & 48 & \\
\cline { 2 - 6 } & Articles & 966 & & 181 & \\
\hline \multirow{2}{*}{$2011-2020$} & Issues & 70 & $47.6 \%$ & 26 & $54.2 \%$ \\
\cline { 2 - 6 } & Articles & 443 & $45.9 \%$ & 103 & $56.9 \%$ \\
\hline \multirow{2}{*}{$2000-2010$} & Issues & 77 & $52.4 \%$ & 22 & $45.8 \%$ \\
\cline { 2 - 6 } & Articles & 523 & $54.1 \%$ & 78 & $43.1 \%$ \\
\hline
\end{tabular}

This amounts to 966 articles in CPA and 181 articles in SEAJ and a combined total of 1147 journal articles. This shows a difference in the journals in terms of scale-with 5.3 papers in CPA for every 1 article in SEAJ, and 3.06 issues in CPA for every 1 issue of SEAJ. The average articles per issue are 6.57 articles per issue and 7.35 issues per annum in CPA. The average is 3.77 articles per issue in SEAJ with an average of 2.4 issues per annum. Over the period, when split into two sections, CPA shows a slight fall in the number of issues and articles (9\% fall in issues and $15.3 \%$ fall in articles) whilst SEAJ shows an increase (18\% increase in issues and $32 \%$ increase in articles). The factors that impact on these changes for the journals are: 2020 is at this point not completed and so further issues and articles will bring up CPA to a closer level during the second period; a meta-analysis of SEAJ [14] highlighted the changes in SEAJ, becoming a comparable journal in 2011 with a move to Routledge and towards peer-reviewed articles, although they maintained the focus on shorter (up to 5000 words) articles. This change has resulted in an increase in articles in SEAJ from an average of 7.1 per year (2000-2010) to 10.9 per year (2011-2019-complete years).

Figure 1 provides an overview of the number of articles in each of the journals per annum.

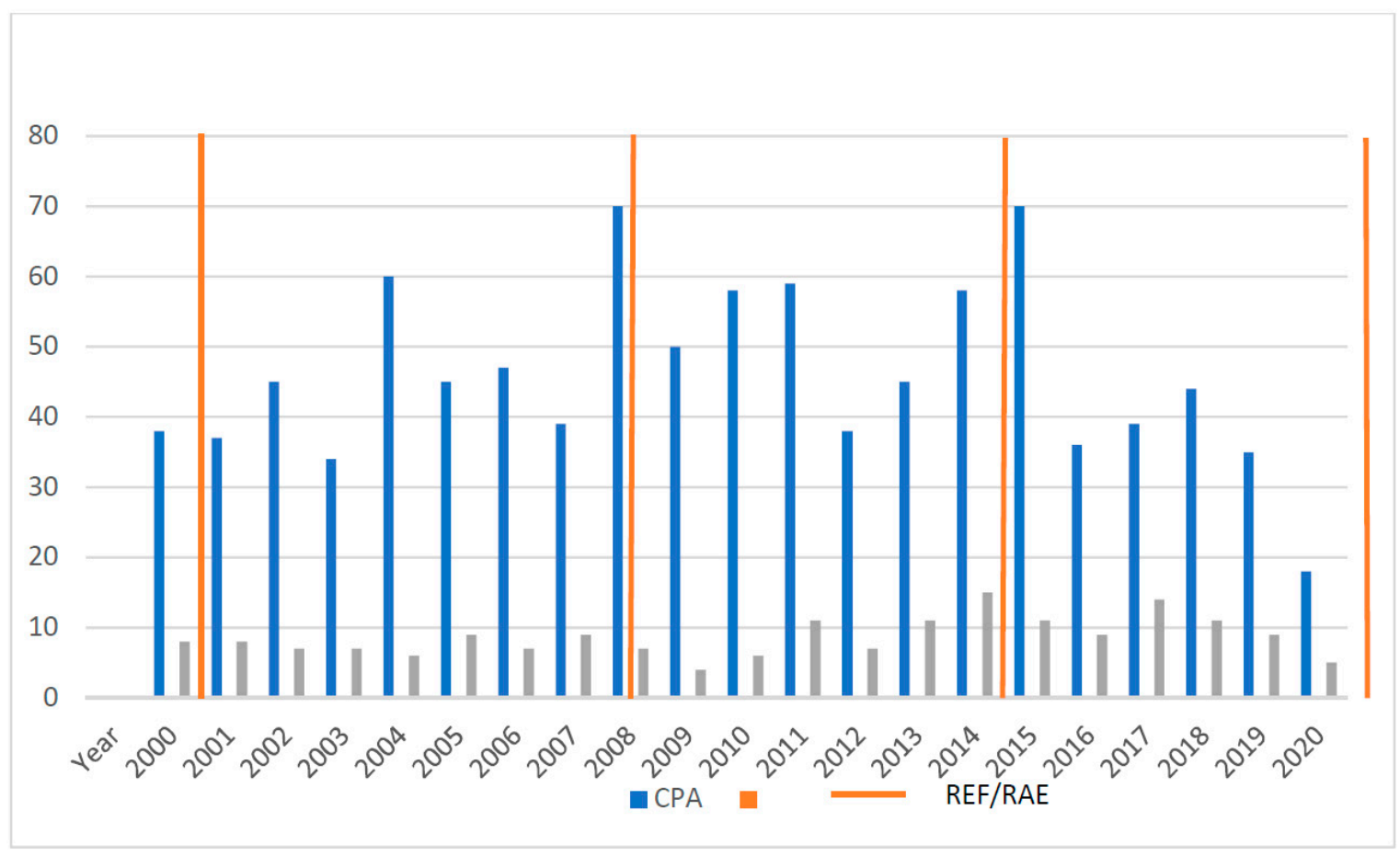

Figure 1. The velocity of articles Critical Perspectives on Accounting (CPA) and Social and Environmental Accountability Journal (SEAJ)—2000-2020.

In Figure 1, time markers for the Research Excellence Framework (REF)/Research Assessment Exercise (RAE) end of periods have been added. These are the UK Higher Education research reviews 
which in the table provide a clear demarcation and periodization to the study and can be connected to article submission rates and publications. This table shows journal article velocity during periods over the sample period 2000 to 2020 .

All of the article titles in the period reviewed were downloaded to an excel file and it is the titles that have been analyzed to establish how research interests have developed post the 2000 original paper [1]. The included articles and general breakdown into themes, detailed in Table 6. To include and or exclude articles in the analysis a keyword analysis was carried out as previously detailed-see Table 2-root and derivative terms and discussion.

Table 6. SEAJ articles included, excluded and theme analysis of included articles.

\begin{tabular}{ccccc}
\hline & Total Articles & $\begin{array}{c}\text { Articles Excluded } \\
\text { Keywords }\end{array}$ & $\begin{array}{c}\text { Articles Excluded- } \\
\text { Reflections/Base Editorials }\end{array}$ & $\begin{array}{c}\text { Articles } \\
\text { Included-Split }\end{array}$ \\
\hline SEAJ & 181 & 48 & 16 & 117 \\
\hline Split themes & & & 63 \\
\hline Analysis & & & 46 \\
\hline Reports & & & 8 \\
\hline Methodology & & & \\
\hline
\end{tabular}

\subsection{A Meta-Analysis of SEAJ Articles 2000-2020}

In terms of the excluded articles, those which had no keyword hits were excluded. There were some 'thought pieces' and short 'base' editorials mainly around the CSEAR management issues which were also excluded. Editorials that added to the issue topic and were more developed (in page and content) were included. The breakdown of the articles was into three groups in Table 6 .

This is based on papers related to environmental reporting coded under reports; general articles were coded as analysis; any papers on methodology and systematic analysis were coded as methodology. The clear direction is the papers either deal with reporting issues $(39.3 \%)$ or are general analytical papers $(53.8 \%)$.

Taking the top 10 articles these are shown in Table 7 and are the top by the number of citations taken from Google Scholar.

All of the papers were read by the author. In terms of analyzing these papers and the environmental direction these provide over the time frame, the most cited paper [23] has been widely cited as it is a good starting point for legitimacy theory and develops the use of the theory, in this small sample this methodological development is not replicated. One theme that emerges in the sample is an interest in corporate environmental reporting (CSR is accepted as a form of this). Four papers directly address environmental reporting $[25,26,28,31]$ and when we add in disclosure concerns as within the corporate reporting area then there are 2 additional papers $[30,32]$ and therefore in total 6 papers in the top 10 are concerned with environmental reporting, reviewing the current status of firms reporting systems on environmental issues. Three papers explore the future role of social-environmental accounting $[24,27,29]$ and how it would benefit from being within a frame of agnostic pluralism [24] how the current tensions within research lead to homogenized research with 2 strands of research dominating; then a specific discussion on carbon accounting now and future challenges [27]; critiques of corporate attitudes and practice and survey-based reports on patterns of action [29]. The final theme is the development of environmental reporting and is related to the context and interest in different countries, including developing countries such as Malaysia [26] and developed nations or states like the EU $[28,31]$. 
Table 7. SEAJ Top 10 articles by citation levels.

\begin{tabular}{|c|c|c|c|c|c|c|}
\hline & Author & Title & Year & $\begin{array}{c}\text { Volume } \\
\text { (Issue), page/s }\end{array}$ & Citations & Ref \\
\hline 1 & Tilling, M. & $\begin{array}{c}\text { Some thoughts on legitimacy } \\
\text { theory in social and } \\
\text { environmental accounting }\end{array}$ & 2004 & $24(2), 3-7$ & 195 & [23] \\
\hline 2 & $\begin{array}{c}\text { Dillard, J, } \\
\text { and Brown, J. }\end{array}$ & $\begin{array}{l}\text { Agonistic Pluralism and } \\
\text { Imagining CSEAR into the } \\
\text { Future }\end{array}$ & 2012 & $32(1), 3-16$ & 64 & [24] \\
\hline 3 & $\begin{array}{c}\text { Unerman, J. } \\
\text { and Zappettini, F. }\end{array}$ & $\begin{array}{c}\text { Incorporating Materiality } \\
\text { Considerations into Analyses } \\
\text { of Absence from } \\
\text { Sustainability Reporting }\end{array}$ & 2014 & $34(3), 172-186$ & 50 & [25] \\
\hline 4 & $\begin{array}{l}\text { Jamil, C., Alwi, K., } \\
\text { and Mohamed R. }\end{array}$ & $\begin{array}{l}\text { Corporate social } \\
\text { responsibility disclosure in } \\
\text { the annual reports of } \\
\text { Malaysian companies: A } \\
\text { longitudinal study }\end{array}$ & 2002 & $22(2), 5-9$ & 50 & [26] \\
\hline 5 & Ascui, F. & $\begin{array}{c}\text { A Review of Carbon } \\
\text { Accounting in the Social and } \\
\text { Environmental Accounting } \\
\text { Literature: What Can it } \\
\text { Contribute to the Debate? }\end{array}$ & 2014 & $34(1), 6-28$ & 49 & [27] \\
\hline 6 & $\begin{array}{l}\text { Luque-Vílchez, M. } \\
\text { and Larrinaga C. }\end{array}$ & $\begin{array}{l}\text { Reporting Models do not } \\
\text { Translate Well: Failing to } \\
\text { Regulate CSR Reporting in } \\
\text { Spain }\end{array}$ & 2016 & $36(1), 56-75$ & 48 & [28] \\
\hline 7 & Parker, L. & $\begin{array}{l}\text { Building Bridges to the } \\
\text { Future: Mapping the } \\
\text { Territory for Developing } \\
\text { Social and Environmental } \\
\text { Accountability }\end{array}$ & 2011 & $31(1), 7-24$ & 48 & [29] \\
\hline 8 & $\begin{array}{l}\text { Guthrie, J., } \\
\text { Cuganesan S., } \\
\text { and Ward, L. }\end{array}$ & $\begin{array}{l}\text { Disclosure media for social } \\
\text { and environmental matters } \\
\text { within the Australian food } \\
\text { and beverage industry }\end{array}$ & 2008 & $28(1), 3-44$ & 43 & [30] \\
\hline 9 & $\begin{array}{l}\text { Hibbitt, C., } \\
\text { and Collison, D. }\end{array}$ & $\begin{array}{l}\text { Corporate environmental } \\
\text { disclosure and reporting } \\
\text { developments in Europe }\end{array}$ & 2004 & $24(1), 1-11$ & 42 & [31] \\
\hline 10 & $\begin{array}{l}\text { Rahman, S., } \\
\text { Yusoff, R., } \\
\text { and Mohamed, W. }\end{array}$ & $\begin{array}{l}\text { Environmental disclosure } \\
\text { and financial performance: } \\
\text { An empirical study of } \\
\text { Malaysia, Thailand, } \\
\text { and Singapore }\end{array}$ & 2009 & $29(2), 45-58$ & 39 & [32] \\
\hline
\end{tabular}

\subsection{A Meta-Analysis of CPA Articles 2000-2020}

The analysis of CPA articles included and excluded from the analysis of environmental papers is shown in Table 8. This follows the same coding in splitting included articles as Table 6.

This is quite different than the SEAJ analysis, the first difference is the small number of relevant articles $7.14 \%$ (69/966) of all articles over the 20 years dealt with environmental concerns. This number was increased by 'special editions'. The special editions relevant to SEA are shown in Table 9. 
Table 8. CPA articles included, excluded and theme analysis of included articles.

\begin{tabular}{cccc}
\hline & Total Articles & Articles Excluded-No Keywords & Articles Included-Split \\
\hline CPA & 966 & 897 & 69 \\
\hline Split themes & & 52 \\
\hline Analysis & & 14 \\
\hline Reports & 3 \\
\hline Methodology & & 3 \\
\hline
\end{tabular}

Table 9. Special issue/editions on environmental accounting issues for CPA 2000-2010.

\begin{tabular}{cccccc}
\hline Year & Volume (Issue) & Special Edition Title & Editors & $\begin{array}{c}\text { Number of } \\
\text { Articles }\end{array}$ & Ref \\
\hline 2015 & 33 & $\begin{array}{c}\text { Social and environmental } \\
\text { accounting }\end{array}$ & $\begin{array}{c}\text { Cho, C. } \\
\text { and Giodarno-Spring, S. }\end{array}$ & 8 & [33] \\
\hline 2015 & 32 & $\begin{array}{c}\text { Quantitative methods and } \\
\text { critical accounting }\end{array}$ & Neu, D. & [34] \\
\hline 2014 & $25(7)$ & $\begin{array}{c}\text { Special section on } \\
\text { accounting for natural } \\
\text { disasters and humanitarian } \\
\text { interventions. }\end{array}$ & Sargiacomo, M. & 6 & {$[35]$} \\
\hline 2013 & $24(6)$ & $\begin{array}{c}\text { Thematic issue: Accounting } \\
\text { for the environment }\end{array}$ & & 8 & {$[36]$} \\
\hline 2008 & $19(4)$ & $\begin{array}{c}\text { Accounting for global } \\
\text { warming }\end{array}$ & Sy, A. & 4 & {$[37]$} \\
\hline
\end{tabular}

Therefore, the special/thematic editions account for $42 \%(29 / 69)$ of the overall articles on environmental issues.

Note: The 2015 Quantitative methods SI is included as these are methodological papers, the focus of three papers was on how these intersected with social and environmental issues which were highlighted in the titles [38-40].

This leaves 69 articles to review, to reduce this to a number that could be reviewed in more depth in this research paper all 69 papers were reviewed under Google scholar for the citation levels, ranked according to citations and the top 10 papers detailed in Table 10 below:

Table 10. CPA—top 10 cited environmental accounting papers 2000-2020.

\begin{tabular}{|c|c|c|c|c|c|c|}
\hline & Authors & Title & Year & $\begin{array}{c}\text { Volume } \\
\text { (Issue) page/s }\end{array}$ & Citations & Ref \\
\hline 1 & $\begin{array}{c}\text { Brown, J., } \\
\text { and Dillard, J. }\end{array}$ & $\begin{array}{l}\text { Agonizing over engagement: } \\
\text { SEA and the "death of } \\
\text { environmentalism" debates }\end{array}$ & 2013 & $24(1), 1-18$ & 2022 & [41] \\
\hline 2 & $\begin{array}{l}\text { Bebbington, J., } \\
\text { and Gray, R. }\end{array}$ & $\begin{array}{l}\text { An Account of Sustainability: } \\
\text { Failure, Success and a } \\
\text { Reconceptualization }\end{array}$ & 2001 & $12(5), 557-587$ & 549 & [42] \\
\hline 3 & Flower, J. & $\begin{array}{c}\text { The International Integrated } \\
\text { Reporting Council: A story of } \\
\text { failure }\end{array}$ & 2015 & $27,1-17$ & 540 & [43] \\
\hline 4 & Adams, C. & $\begin{array}{l}\text { The International Integrated } \\
\text { Reporting Council: A call to } \\
\text { action }\end{array}$ & 2015 & $27,23-28$ & 437 & [44] \\
\hline
\end{tabular}


Table 10. Cont.

\begin{tabular}{|c|c|c|c|c|c|c|}
\hline & Authors & Title & Year & $\begin{array}{c}\text { Volume } \\
\text { (Issue) page/s }\end{array}$ & Citations & Ref \\
\hline 5 & $\begin{array}{l}\text { Michelon, G., } \\
\text { Pilonato, S. } \\
\text { and Ricceri, F. }\end{array}$ & $\begin{array}{l}\text { CSR reporting practices and } \\
\text { the quality of disclosure: An } \\
\text { empirical analysis }\end{array}$ & 2015 & $33,59-78$ & 406 & {$[45]$} \\
\hline 6 & $\begin{array}{l}\text { Rahaman, A., } \\
\text { Lawrence, S., } \\
\text { and Roper, J. }\end{array}$ & $\begin{array}{l}\text { Social and environmental } \\
\text { reporting at the VRA: } \\
\text { institutionalised legitimacy or } \\
\text { legitimation crisis? }\end{array}$ & 2004 & $15(1), 35-56$ & 385 & [46] \\
\hline 7 & $\begin{array}{l}\text { Thomson, I. } \\
\text { and Bebbington, J. }\end{array}$ & $\begin{array}{l}\text { Social and environmental } \\
\text { reporting in the UK: a } \\
\text { pedagogic evaluation }\end{array}$ & 2005 & $16(5), 507-533$ & 362 & [47] \\
\hline 8 & Brown, J. & $\begin{array}{l}\text { Democracy, sustainability, } \\
\text { and dialogic accounting } \\
\text { technologies: Taking } \\
\text { pluralism seriously }\end{array}$ & 2009 & $20(3), 313-342$ & 322 & [48] \\
\hline 9 & $\begin{array}{l}\text { Mahoney, L., } \\
\text { Thorne, L., Cecil, L., } \\
\text { and LaGore, W. }\end{array}$ & $\begin{array}{l}\text { A research note on } \\
\text { standalone corporate social } \\
\text { responsibility reports: } \\
\text { Signaling or greenwashing? }\end{array}$ & 2013 & $\begin{array}{l}24(4-5) \\
350-359\end{array}$ & 319 & [49] \\
\hline 10 & $\begin{array}{l}\text { Larrinaga-Gonzalez, C. } \\
\text { and Bebbington, J. }\end{array}$ & $\begin{array}{l}\text { Accounting change or } \\
\text { institutional } \\
\text { appropriation?-A case study } \\
\text { of the implementation of } \\
\text { environmental accounting }\end{array}$ & 2001 & 12(3), 269-292 & 311 & {$[50]$} \\
\hline
\end{tabular}

All of the CPA papers were read by the author. In terms of the themes that emerge, there are discussions around monologic (consensus) views and interpretations of social and environmental as against dialogic (plural and or adversarial) [41,48]. Additionally, the emancipatory potential of SEA [47] as against the limitations and need to reconceptualize accounting [42]. Social and environmental reporting is another significant issue to emerge. The Integrated Reporting (IR) process is seen as corporate capture of the social and environmental debate and value creation for just investors [43] whilst more positively IR is seen as not meant to be focused on sustainability and a way to make accounting look at the long term [44]. Social and environmental reporting is seen as a signaling process with only stand-alone reports adding to quantity in terms of CSR $[45,49]$ and the environmental reporting process required by external funders (World Bank in this case) leading in developing countries to detrimental social issues [46].

Overall the works are more theoretically developed, more critical, and focused on social concerns even more than the environmental aspects of the analysis. This comes out most in the analysis of the CSR reports. The highest citations in CPA environmental accounting when split between 2000-2010-5, and 2011-2020 - 5. This is more evenly spread in the first period, and then in the second period related to articles in 2013 and 2015, with no subsequent articles in the top 10 cited since 2015. There was only one instance of highly cited papers from the same volume [43,44]. Only two articles can be found related to environmental accounting since 2018 and are shown in Table 11.

A final point is the connections between the SEAJ and CPA articles. In terms of the authors, there were 20 separate authors involved in the 10 SEAJ papers and 18 separate authors of CPA papers. There were 4 authors with papers in both journals (Brown; Dillard; Larrinaga and Rahman); 1 author with 2 papers in CPA (Brown), and 1 author with 3 papers in CPA (Bebbington). This highlights the small number of academics who have been working in the social and environmental area, and also the cross over in terms of the authors publishing in both journals, though the research process including keyword searches was the same in both journals and so the connections in terms of overlapping authorship are not unexpected. 
Table 11. CPA recent environmental accounting papers 2019-2020.

\begin{tabular}{|c|c|c|c|c|c|c|}
\hline & Authors & Title & Year & $\begin{array}{c}\text { Volume } \\
\text { (Issue) page/s }\end{array}$ & Citations & Ref \\
\hline 1 & $\begin{array}{c}\text { She, C. } \\
\text { and Michelon, G. }\end{array}$ & $\begin{array}{l}\text { Managing stakeholder perceptions: } \\
\text { Organized hypocrisy in CSR } \\
\text { disclosures on Facebook }\end{array}$ & 2019 & $61,54-76$ & 18 & [51] \\
\hline 2 & $\begin{array}{l}\text { Bebbington, J., } \\
\text { Schneider, T., } \\
\text { Stevenson, L., } \\
\text { and Fox, A. }\end{array}$ & $\begin{array}{l}\text { Fossil fuel reserves and resources } \\
\text { reporting and unburnable carbon: } \\
\text { Investigating conflicting accounts }\end{array}$ & 2020 & 66 , online & 12 & [52] \\
\hline
\end{tabular}

\subsection{Citation Analysis-Articles from Any Journal}

To find out how the articles and issues have developed combined with the meta-analysis of the journals, a citation review has been carried out. This provides details of the most cited and therefore influential articles citing the work of [1,2].

Google Scholar has been used as the citation dataset for the analysis. The central paper in this review is [1], as this is where the analysis stems from. [1] has 80 citations, the top 10 have been included in Table 12 .

Table 12. Journals citing Birkin (2000) [1] with the highest citation value (Google Scholar).

\begin{tabular}{|c|c|c|c|c|c|}
\hline Author/s & Title & Year & Journal & Citations & Ref \\
\hline Bebbington, J. & $\begin{array}{l}\text { Sustainable development: a review of } \\
\text { the international development, business } \\
\text { and accounting literature }\end{array}$ & 2001 & $\begin{array}{l}\text { Accounting } \\
\text { Forum }\end{array}$ & 422 & [53] \\
\hline $\begin{array}{l}\text { Bebbington, J., } \\
\text { Brown, J., } \\
\text { and Frame, B. }\end{array}$ & $\begin{array}{c}\text { Accounting technologies and } \\
\text { sustainability assessment models }\end{array}$ & 2007 & $\begin{array}{l}\text { Ecological } \\
\text { Economics }\end{array}$ & 405 & [54] \\
\hline $\begin{array}{c}\text { Dumay, J., } \\
\text { Guthrie, J., } \\
\text { and Farneti, F. }\end{array}$ & $\begin{array}{l}\text { GRI sustainability reporting guidelines } \\
\text { for public and third sector } \\
\text { organizations: A critical review }\end{array}$ & 2010 & $\begin{array}{c}\text { Public } \\
\text { Management } \\
\text { Review }\end{array}$ & 290 & [55] \\
\hline $\begin{array}{l}\text { Ball, A., } \\
\text { and Craig, R. }\end{array}$ & $\begin{array}{l}\text { Using neo-institutionalism to advance } \\
\text { social and environmental accounting }\end{array}$ & 2010 & $\begin{array}{l}\text { Critical } \\
\text { Perspectives on } \\
\text { Accounting }\end{array}$ & 230 & [56] \\
\hline Ball, A. & $\begin{array}{l}\text { Environmental accounting and change } \\
\text { in UK local government }\end{array}$ & 2005 & $\begin{array}{l}\text { Accounting, } \\
\text { Auditing \& } \\
\text { Accountability } \\
\text { Journal }\end{array}$ & 222 & [57] \\
\hline $\begin{array}{l}\text { Xing, Y., Horner, R., } \\
\text { El-Haram, M., } \\
\text { and Bebbington, J. }\end{array}$ & $\begin{array}{l}\text { A framework model for assessing } \\
\text { sustainability impacts of urban } \\
\text { development }\end{array}$ & 2009 & $\begin{array}{l}\text { Accounting } \\
\text { Forum }\end{array}$ & 171 & [58] \\
\hline O’Dwyer, B. & $\begin{array}{l}\text { Stakeholder democracy: challenges and } \\
\text { contributions from social accounting }\end{array}$ & 2005 & $\begin{array}{l}\text { Business Ethics: } \\
\text { A European } \\
\text { Review }\end{array}$ & 161 & [59] \\
\hline $\begin{array}{l}\text { Birkin, F., } \\
\text { Polesie, T., } \\
\text { and Lewis, L. }\end{array}$ & $\begin{array}{l}\text { A new business model for sustainable } \\
\text { development: an exploratory study } \\
\text { using the theory of constraints in } \\
\text { Nordic organizations }\end{array}$ & 2009 & $\begin{array}{l}\text { Business } \\
\text { Strategy and } \\
\text { the } \\
\text { Environment }\end{array}$ & 153 & [60] \\
\hline $\begin{array}{l}\text { Birkin, F., } \\
\text { Cashman, A., } \\
\text { and Koh, S. }\end{array}$ & $\begin{array}{c}\text { New sustainable business models in } \\
\text { China }\end{array}$ & 2009 & $\begin{array}{l}\text { Business } \\
\text { Strategy and } \\
\text { the } \\
\text { Environment }\end{array}$ & 145 & [61] \\
\hline Everett, J. & $\begin{array}{l}\text { Exploring (false) dualisms for } \\
\text { environmental accounting praxis }\end{array}$ & 2004 & $\begin{array}{l}\text { Critical } \\
\text { Perspectives on } \\
\text { Accounting }\end{array}$ & 116 & [62] \\
\hline
\end{tabular}

This provides a snapshot from a spread of journals (7 different journals) with only 3 journals with 2 papers from each (Accounting Forum; Critical Perspectives on Accounting; Business Strategy and the 
Environment). There are also 18 different authors, with Birkin and Ball having 2 papers [56,57,60,61], and Bebbington involved in 3 papers [53,54,58]. All of the papers were published in 2010 and before, with half of the papers being in 2009 and 2010 [55,56,58,60,61].

The themes that emerge include, the almost universal challenge to the term sustainable development in the business community. The environmental and ecological aspects of the sustainability and SEA are brought out, with a view that SD isn't about good environmental management but more about the economic system that means needs are met in an environmental and socially just manner [54]; fundamental challenges to the process of SD in business, with a view the GRI guidelines are managerialist [56], environmental accounting leads to deinstitionalisation [54], social and environmental accounting needs to be more democratic for stakeholders [60] and challenge the 'false dualisms' the hold back environmental accounting, more flexible approaches are needed for practitioners and researchers [63]; the creation of new business models, that create monetized values as well as understanding limits to consumption $[55,61,62]$.

Citations develop over time so an analysis of articles and research connected to a citation review in terms of the number of citations will increase over a while. In this sense, there is an aspect of older articles that have more heavily cited articles connected to them. To explore this issue Google Scholar was analysed in terms of the citations connected to [1] but only since 2016. This only had two published articles with citations-Table 13.

Table 13. Articles citing Birkin (2000) [1] with the highest citation levels since 2016 (Google Scholar).

\begin{tabular}{|c|c|c|c|c|c|}
\hline Author/s & Title & Year & Journal & Citations & Ref \\
\hline $\begin{array}{c}\text { Feger, C., } \\
\text { and Mermet, L. }\end{array}$ & $\begin{array}{l}\text { A blueprint towards accounting } \\
\text { for the management of } \\
\text { ecosystems }\end{array}$ & 2017 & $\begin{array}{l}\text { Accounting, } \\
\text { Auditing \& } \\
\text { Accountability } \\
\text { Journal }\end{array}$ & 23 & [63] \\
\hline $\begin{array}{l}\text { Zhou, Z., Ou, J., } \\
\text { and Li, S. }\end{array}$ & $\begin{array}{c}\text { Ecological accounting: a } \\
\text { research review and conceptual } \\
\text { framework }\end{array}$ & 2016 & $\begin{array}{l}\text { Journal of } \\
\text { Environmental } \\
\text { Protection }\end{array}$ & 7 & [64] \\
\hline
\end{tabular}

These provide some guidance on issues that are current in terms of the ecological management accounting debate. As an example, there is an approach created that is termed Accounting For the Management of Ecosystems (AFME) [63]. This builds on the work of the ecosystems research (wider perspective than organizations) and also the accounting for biodiversity work. More cross-disciplinary research is suggested and this would change the focus from organizations to 'organized action settings' [63] (p. 1524).

There is also a look at the evolution of an ecological management accounting process from past research themes [64]. Whilst there is some acknowledgement of the challenges of this process, the analysis is more of a 'systems-based' approach (being able to add one system to another). The challenges set out include creating a central theoretical construct, developing accounting approaches in the ecological analysis (using a systems-theory approach), and carrying out more empirical research inclusive of developing country contexts [64].

In terms of [2] has according to Google Scholar 21 citations. Only articles with 2 or more citations have been included. Table 14 details the articles citing [2].

The original paper [2] is a later paper, 2018, the citation details are less developed-following the example of [1] most papers were published 9/10 years after the initial article, which in the case of [2] would therefore be 2027/8. Whilst [2] provides a more to date interpretation of accounting and environmental issues and is explored comparatively in its own right, it is also beneficial to explore the papers that cite and connect with [2], though due to time challenges (including publication time lags) these papers are likely to be small in number. Six articles cite the paper more than twice. There are 15 different authors, with no author appearing more than once and the authors not appearing in the other tables. 
Table 14. Articles citing Schaltegger (2018) [2] with the highest citation value (Google Scholar).

\begin{tabular}{|c|c|c|c|c|c|}
\hline Author/s & Title & Year & Journal & Citations & Ref \\
\hline $\begin{array}{c}\text { Gibassier, D. } \\
\text { and Alcouffe, S. }\end{array}$ & $\begin{array}{l}\text { Environmental management } \\
\text { accounting: the missing link to } \\
\text { sustainability? (Editorial) }\end{array}$ & 2018 & $\begin{array}{c}\text { Social } \\
\text { Environmental } \\
\text { Accountability } \\
\text { Journal }\end{array}$ & 18 & [65] \\
\hline $\begin{array}{l}\text { Gomez-Conde, J., } \\
\text { Lunkes, R. } \\
\text { and Rosa, F. }\end{array}$ & $\begin{array}{c}\text { Environmental innovation } \\
\text { practices and operational } \\
\text { performance }\end{array}$ & 2019 & $\begin{array}{l}\text { Accounting, } \\
\text { Auditing \& } \\
\text { Accountability } \\
\text { Journal }\end{array}$ & 14 & [66] \\
\hline $\begin{array}{l}\text { Wang, S., Wang, H. } \\
\text { and Wang, J. }\end{array}$ & $\begin{array}{l}\text { Exploring the effects of } \\
\text { institutional pressures on the } \\
\text { implementation of } \\
\text { environmental management } \\
\text { accounting: Do top } \\
\text { management support and } \\
\text { perceived benefit work? }\end{array}$ & 2019 & $\begin{array}{c}\text { Business } \\
\text { Strategy and } \\
\text { the } \\
\text { environment }\end{array}$ & 10 & [67] \\
\hline Johnstone, L. & $\begin{array}{c}\text { Theorising and conceptualising } \\
\text { the sustainability control system } \\
\text { for effective sustainability } \\
\text { management }\end{array}$ & 2019 & $\begin{array}{l}\text { Journal of } \\
\text { Management } \\
\text { Control }\end{array}$ & 2 & [68] \\
\hline $\begin{array}{l}\text { Christine, D., } \\
\text { Yadiati, W., } \\
\text { and Afiah, N. }\end{array}$ & $\begin{array}{l}\text { The relationship of } \\
\text { environmental management } \\
\text { accounting, environmental } \\
\text { strategy, and managerial } \\
\text { commitment to environmental } \\
\text { performance and economic } \\
\text { performance }\end{array}$ & 2019 & $\begin{array}{l}\text { International } \\
\text { Journal of } \\
\text { Energy } \\
\text { Economics and } \\
\text { Policy }\end{array}$ & 2 & [69] \\
\hline $\begin{array}{c}\text { Laasch, O., } \\
\text { Moosmayer, D., } \\
\text { and } \\
\text { Antonacopoulou, E. }\end{array}$ & $\begin{array}{c}\text { Constellations of } \\
\text { Transdisciplinary Practices: A } \\
\text { Map and Research Agenda for } \\
\text { the Responsible Management } \\
\text { Learning Field }\end{array}$ & 2020 & $\begin{array}{c}\text { Journal of } \\
\text { Business Ethics }\end{array}$ & 2 & [70] \\
\hline
\end{tabular}

In terms of the findings, the linkage of EMA and Sustainability are explored as separate steams with limited cross over [65]. Three of the papers explore the development of environmental management accounting systems in firms-including how this can trigger environmental innovation [66], and how control systems can be both within and over the organization systems-extending the framework for control [68] and have a positive impact on environmental strategies [69].

In this section, the findings from the meta-analysis of the two journals have been developed as well as an overall citation analysis (most cited papers referencing the original articles). These have been discussed separately in this section and in the following sections. In the discussion section, the findings are combined and reviewed in terms of findings from the formative paper [1], in terms of differences between the two journals and citation analysis. In the conclusion section, the key findings from this work are developed as well as limitations and future research directions.

\section{Discussion}

There are three sets of data used in the analysis of ecological management accounting since 2000 [1]. The three areas of analysis are the development of Birkin (2000) [1] by Schaltegger (2018) [2] and others, referring back to the literature review discussion; phase two is the meta-analysis of the journals-CPA and SEAJ; the final stage is the citation analysis of the two papers. 
There are areas of consensus and dissensus throughout these sections of the research, the issues are specifically developed in each phase before the central themes are sketched out in the conclusion section, where areas for further research are identified.

\subsection{Following Birkin (2000)}

There is discussion around terminology, separating ecological accounting, in a two-step process (Step 1-from economics to environmental economics, step 2-from environmental economics to economic ecology) [1] (p. 295-300). In terms of step 1, an explanation of environmental economics is "Economic efficiency remains as the core activity but the concept of business activity is expanded to accommodate environmental impact(s)" [1] (p. 296). Whilst environmental concerns are still seen at the margins of business activity, a main driver behind environmental economics has been the growth in environmental reporting. The later work [2] never develops step 2 of the process and is concerned with environmental management accounting and the connections with the dominant sustainability concept. There is a process developed involving a more 'relationship' value approach rather than discrete values - a fundamental change to the ontology in accounting [1].

Further identified areas for development: targeting eco-efficiency (widening this to include issues such as eco-justice), a resource flow model depicted the complexity of the organization resources flows with stakeholders, and wider planetary carrying capacity [1] (p. 304). This develops with an approach to link the micro firm view to nine macro planetary boundaries [2] (Table 1) (p. 24). In this sense, this is a practical evolution of the movement towards ecological accounting as proposed in 2000 [1]. Holding to one side the terminological arguments over ecological and or environmental accounting and sustainable development, the fundamental bridging of planetary carrying capacity levels and organization resources use and even shows the interrelationship with the social issue [2] (p. 25).

\section{2. $C P A$ and $S E A J$}

In terms of the overall relevant environmental/ecological accounting papers, the CPA analysis shows a paucity of environmental accounting concerns which perhaps seems worse due to the EMA focus of SEAJ.

When exploring the themes that emerge, with SEAJ and CPA the focus is on environmental reporting analysis and the relationship of economic and environmental performance indicators. In CPA, the reasons for reporting are explored-as a signaling process, at the request of investors (such as the World Bank), though this has led to social detriment [46]. CPA develop this a little more in terms of Integrated Reporting (developed with the influence of accountants for investors). Challenges to basic tenets and premises of environmental accounting do occur-with Dillard and Brown appearing in both SEAJ and CPA [24,41] highlighting the need to work on different versions of the outcomes-an agnostic pluralism rather than a dichotomized view of the environment and business. The main rationale for this call is due to the domination of the economic rationale, overpowering other voices and interpretations, and so minimal change occur. In SEAJ the issue around legitimacy and organizations [23] is also connected with environmental debate, aligned to the view that firms must be aware of social changes and take into account society's increased environmental concerns e.g. Extinction Rebellion have been developing a more high profile campaign around environmental concerns [15].

\subsection{Citation Analysis}

As these are highly cited articles that cite [1] and or [2], it is to be expected that there is more of a focus on environmental concerns. The first issue is around the terminology, the concerns with the usage of sustainable development, this term is viewed from an economic model perspective, not a wider 'good environmental management' [13]. Some of those cited after Schaltegger do separate sustainability and environmental management accounting as two clear research streams $[65,69,70]$. The environmental reporting process itself is seen as reductionist and managerialist and that a wider purview of stakeholders needs to be included in the debates [70]. This may also be a way beyond 
the constraining false dualisms of the debates [62], one example is encapsulated in the argument of economic benefit and environmental loss [55]. More flexible value creation in environmental accounting is required, which again must link in with planetary needs and not just the needs and wants of investors [69]. There is some more positivity from the later papers that increased environmental accounting reporting, leading to environmental adaptations $[63,64]$ and even the idea of extending the control systems to outside organizations commonly seen boundaries. Accounting For the Management of Ecosystems (AFME) is one development of this wider context to view and control organization performance [63]. Even going back to the development of these approaches must be cross-disciplinary and must be more than just the accounting team [70].

\section{Conclusions}

Several themes emerged throughout the analysis, the first is around terminology and its impreciseness and multiple usages of terms. Of most concern is the concept of sustainability, which is seen as a connected, interchangeable, and over-arching concept and, in many ways, has hindered the development of environmental management accounting [42]. The concept of ecological accounting has not been used to any note in the period since 2000 [1]. Environmental management accounting is more of a favoured term and is positioned as separate from sustainability, this may be a clearer way forward [63]. Research papers must take care of the terminology used [1]. The use of environmental and accounting can provide a clearer path along which environmental concerns and accounting can be developed. This may be towards sustainable development objectives, but the specific environmental/ecological management accounting terms can be developed as useful frames supportive of research in this area $[63,69,70]$.

Another significant issue is the stakeholders or groups included in the debates. Alongside mainstream accounting research that has become more aware of stakeholders of the firm, more entities need including in the environmental accounting debates [67]. These could be living and non-living entities [1]. The environment cannot speak for itself and operating in an anthropomorphic environment, the concerns and impacts on the voiceless entity will be marginalized. The environmental entity must be central to any debate on ecological development. This means starting with the impact on the environment and working backwards to the organization-changing the emphasis allows a clearer ecological standard to be established and not seen as a nice add on [68,70].

The issue around the organization and planetary boundaries not being aligned links to the comments around putting the importance of the environment central to the development of ecological accounting [70]. This brings together global planetary concerns with small and local organization issues. The relationship between these two groupings needs to be more carefully developed. There are already some approaches that may help with this process-Accounting For the Management of Ecosystems [63] and Material Flow Cost Accounting [12] are two good examples of approaches that are starting to build the bridge between how the organization measures value on environmental issues, and the planetary measures and values. Further development of these accounting approaches, with an awareness of the factors impacting on the development of ecological accounting, will help shape the development of ecological management accounting into the near future [10,70].

Limitations in this work, excluding the normal limitations of any research work, include the focus on two journals-CPA and SEAJ—whilst they provide distinct views on the development of ecological accounting they cannot be representative of all journals even in the accounting field. A review of a wider range of accounting journals would add to this research work.

Another limitation has been the focus on the titles of the research carried out, as a way to establish if the work was within the remit of this analysis in keyword searches. The title of an article may not include the keywords even though the article may cover the environmental/ecological area. The titles were all scrutinized by the author to see if they did cover respective issues, but articles may have been erroneously excluded from the analysis. The work has attempted to be transparent in the research process, in terms of the research instruments used to analyze the journals they are available to review. 
The findings from a later original paper [2] included that the analysis of citing journals is not fully developed as the publication process means papers that may want to cite this work and are looking at this area of study are still in process. This is something that will only be known over time.

The final issue is that the journal analysis and coding were primarily carried out by one author and so this means one-coder bias is probable. To mitigate this issue at all points a transparent and detailed research process has been provided. Further research projects using this data need to take this into account.

In terms of future research directions, this work shows a dearth of analysis on environmental concerns-with general accounting journals (in this work in the guise of CPA) showing limited interest in this topic. Additionally, there are a number of more environmentally focused journals (in addition to SEAJ analyzed in this work, see for example Accounting, Auditing and Accountability Journal, Sustainability Accounting Management and Policy Journal, Journal of Environmental Accounting and Management). In exploring these journals, there is still a question around the development of a form of 'ecological' accounting. An alternative review could take place of the development of environmental accounting over a time period.

The final suggestion for further research is in terms of the 'planetary boundaries' [2] and how the relationship between an organization and planetary environmental concerns have started to be bridged using concepts such as AFME [63] and Material Flow Cost Accounting [12]. Further research in these areas would fruitfully develop environmental accounting and may even support and encourage the creation of a stand-alone ecological accounting field.

Funding: This research received no external funding.

Acknowledgments: Gratitude to the editorial staff in Sustainability MDPI for guidance in managing the special issue, Environmental Management Accounting (EMA) for sustainable development (ISSN 2071-1050).

Conflicts of Interest: The authors declare no conflict of interest.

\section{References}

1. Birkin, F. The art of accounting for science: A prerequisite for sustainable development? Crit. Perspect. Account. 2000, 11, 289-309. [CrossRef]

2. Schaltegger, S. Linking environmental management accounting: A reflection on (missing) links to sustainability and planetary boundaries. Soc. Environ. Account. J. 2018, 38, 19-29. [CrossRef]

3. Gladwin, T.; Kennelly, J.; Krause, T.-S. Shifting paradigms for sustainable development: Implications for management theory and research. Acad. Manag. Rev. 1995, 20, 874-907. [CrossRef]

4. Moses, O.; Mohaimen, F.; Emmanuel, M. A meta review of SEAJ: The past and projections for 2020 and beyond. Soc. Environ. Account. J. 2020, 40, 24-41. [CrossRef]

5. Ullman, A. The corporate environmental accounting system: A management tool for fighting environmental degradation. Account. Organ. Soc. 1976, 1, 71-79. [CrossRef]

6. Gray, R. The Greening of Accountancy: The Professional after Pearce; Research Report 17; Association of Chartered Certified Accountants: London, UK, 1990; Available online: https://www.researchgate.net/profile/ Rob_Gray11/publication/329220785_The_Greening_of_Accountancy_The_Profession_After_Pearce/links/ 5bfd8472299bf1c2329e6f67/The-Greening-of-Accountancy-The-Profession-After-Pearce.pdf (accessed on 1 October 2020).

7. ACCA. The Sustainable Development Goals: Redefining Context, Risk and Opportunity. ACCA Report. 2017. Available online: https://www.accaglobal.com/hk/en/professional-insights/global-profession/the-sustainabledevelopment-goals.html (accessed on 24 October 2020).

8. Mathews, M.R. Twenty-five years of social and environmental accounting research: Is there a silver jubilee to celebrate? Account. Audit. Account. J. 1997, 10, 481-531. [CrossRef]

9. Gray, R.; Bebbington, J. Accounting for the Environment; Paul Chapman Publishing: London, UK, 1993; ISBN 1-85396-223-6.

10. Schaltegger, S.; Burritt, R. Contemporary Environmental Accounting; Routledge: Oxfordshire, UK, 2017; ISBN 1-87471-935-9. 
11. Elkington, J. Cannibals with Forks; the Triple Bottom Line of 21st Century Business; Capstone: Oxford, UK, 1999; ISBN 1-84112-084-7.

12. Tran, T.; Herzig, C. Material flow cost accounting in developing countries: A systematic review. Sustainability 2020, 12, 5413. [CrossRef]

13. Gray, R.; Bebbington, J. Environmental accounting, managerialism, and sustainability: Is the planet safe in the hands of business and accounting? In Advances in Environmental Accounting \& Management; Emerald Group Publishing Limited: Bingley, UK, 2000; Volume 1, pp. 1-44. [CrossRef]

14. Deegan, C. Twenty-five years of social and environmental accounting research within Critical Perspectives of Accounting: Hits, misses and ways forward. Crit. Perspect. Account. 2017, 43, 65-87. [CrossRef]

15. Mason, P. Tackling the climate crisis means the end of capitalism as we know it. NewStatesman. 26 June 2019. Available online: https://www.newstatesman.com/politics/economy/2019/06/tackling-climate-crisis-meansend-capitalism-we-know-it (accessed on 2 October 2020).

16. Uhlmann, D. BP paid a steep price for the Gulf oil spill but for the US a decade later, it's business as usual. The Conversation. 23 April 2020. Available online: https://theconversation.com/bp-paid-a-steep-price-for-thegulf-oil-spill-but-for-the-us-a-decade-later-its-business-as-usual-136905 (accessed on 1 October 2020).

17. PRISMA. Checklist. 2009. Available online: http://www.prisma-statement.org/ (accessed on 27 August 2020).

18. Durach, C.; Kembro, J.; Wieland, A. A new paradigm for systematic literature reviews in supply chain management. J. Supply Chain Manag. 2017, 53, 67-85. [CrossRef]

19. Chartered Association of Business Schools. Academic Journal Guide 2018. Available online: https: //charteredabs.org/academic-journal-guide-2018/ (accessed on 1 October 2020).

20. IFAC. International Guidance Document-Environmental Management Accounting. August 2005. Available online: https://www.ifac.org/system/files/publications/files/international-guidance-docu-2.pdf (accessed on 27 August 2020).

21. Critical Perspectives on Accounting, Aims, and Scope. Available online: https://www.journals.elsevier.com/ critical-perspectives-on-accounting (accessed on 18 July 2020).

22. Social and Environmental Accountability Journal, Aims and Scope. Available online: https://www.tandfonline. com/action/journalInformation?show=aimsScope\&journalCode=reaj20 (accessed on 18 July 2020).

23. Tilling, M. Some thoughts on legitimacy theory in social and environmental accounting. Soc. Environ. Account. J. 2004, 24, 3-7. [CrossRef]

24. Dillard, J.; Brown, J. Agonistic Pluralism and Imagining CSEAR into the Future. Soc. Environ. Account. J. 2012, 32, 3-16. [CrossRef]

25. Unerman, J.; Zappettini, F. Incorporating materiality considerations into analyses of absence from sustainability reporting. Soc. Environ. Account. J. 2014, 34, 172-186. [CrossRef]

26. Jamil, C.; Alwi, K.; Mohamed, R. Corporate social responsibility disclosure in the annual reports of Malaysian companies: A longitudinal study. Soc. Environ. Account. J. 2002, 22, 5-9. [CrossRef]

27. Ascui, F. A review of carbon accounting in the social and environmental accounting literature: What can it contribute to the debate? Soc. Environ. Account. J. 2014, 34, 6-28. [CrossRef]

28. Luque-Vílchez, M.; Larrinaga, C. Reporting models do not translate well: Failing to regulate CSR reporting in Spain. Soc. Environ. Account. J. 2016, 36, 56-75. [CrossRef]

29. Parker, L. Building bridges to the future: Mapping the territory for developing social and environmental accountability. Soc. Environ. Account. J. 2011, 31, 7-24. [CrossRef]

30. Guthrie, J.; Cuganesan, S.; Ward, L. Disclosure media for social and environmental matters within the Australian food and beverage industry. Soc. Environ. Account. J. 2008, 28, 33-44. [CrossRef]

31. Hibbitt, C.; Collison, D. Corporate environmental disclosure and reporting developments in Europe. Soc. Environ. Account. J. 2004, 24, 1-11. [CrossRef]

32. Rahman, S.; Yusoff, R.; Mohamed, W. Environmental disclosure and financial performance: An empirical study of Malaysia, Thailand and Singapore. Soc. Environ. Account. J. 2009, 29, 45-58. [CrossRef]

33. Cho, C.; Giodarno-Spring, S. (Eds.) Social and environmental accounting. Crit. Perspect. Account. 2015, 33, 1-136. Available online: https://www.sciencedirect.com/journal/critical-perspectives-on-accounting/vol/33/ suppl/C (accessed on 24 October 2020). [CrossRef]

34. Neu, D. (Ed.) Quantitative methods and critical accounting. Crit. Perspect. Account. 2015, 32, 1-88. Available online: https://www.sciencedirect.com/journal/critical-perspectives-on-accounting/vol/32/suppl/C (accessed on 24 October 2020). 
35. Sargiacomo, M. (Ed.) Special section on accounting for natural disasters and humanitarian interventions. Crit. Perspect. Account. 2014, 25, 539-670. Available online: https://www.sciencedirect.com/journal/criticalperspectives-on-accounting/vol/25/issue/7 (accessed on 24 October 2020).

36. Thematic issue: Accounting for the environment. Crit. Perspect. Account. 2013, 24, 397-478. Available online: https://www.sciencedirect.com/journal/critical-perspectives-on-accounting/vol/24/issue/6 (accessed on 24 October 2020).

37. Sy, A. (Ed.) Accounting for global warming. Crit. Perspect. Account. 2008, 19, 431-572. Available online: https://www.sciencedirect.com/journal/critical-perspectives-on-accounting/vol/19/issue/4 (accessed on 24 October 2020).

38. Gray, R.; Milne, M. It's not what you do, it's the way that you do it? Of method and madness. Crit. Perspect. Account. 2015, 32, 51-66. [CrossRef]

39. Patten, D. An insider's reflection on quantitative research in the social and environmental disclosure domain. Crit. Perspect. Account. 2015, 32, 45-50. [CrossRef]

40. Roberts, R.; Wallace, D. Sustaining diversity in social and environmental accounting research. Crit. Perspect. Account. 2015, 32, 78-87. [CrossRef]

41. Brown, J.; Dillard, J. Agonizing over engagement: SEA and the "death of environmentalism" debates. Crit. Perspect. Account. 2013, 24, 1-18. [CrossRef]

42. Bebbington, J.; Gray, R. An account of sustainability: Failure, success and a reconceptualization. Crit. Perspect. Account. 2001, 12, 557-587. [CrossRef]

43. Flower, J. The international integrated reporting council: A story of failure. Crit. Perspect. Account. 2015, 27, 1-17. [CrossRef]

44. Adams, C. The international integrated reporting council: A call to action. Crit. Perspect. Account. 2015, 27, 23-28. [CrossRef]

45. Michelon, G.; Pilonato, S.; Ricceri, F. CSR reporting practices and the quality of disclosure: An empirical analysis. Crit. Perspect. Account. 2015, 33, 59-78. [CrossRef]

46. Rahaman, A.; Lawrence, S.; Roper, J. Social and environmental reporting at the VRA: Institutionalised legitimacy or legitimation crisis? Crit. Perspect. Account. 2004, 15, 35-56. [CrossRef]

47. Thomson, I.; Bebbington, J. Social and environmental reporting in the UK: A pedagogic evaluation. Crit. Perspect. Account. 2005, 16, 507-533. [CrossRef]

48. Brown, J. Democracy, sustainability, and dialogic accounting technologies: Taking pluralism seriously. Crit. Perspect. Account. 2009, 20, 313-342. [CrossRef]

49. Mahoney, L.; Thorne, L.; Cecil, L.; LaGore, W. A research note on standalone corporate social responsibility reports: Signaling or greenwashing? Crit. Perspect. Account. 2013, 24, 350-359. [CrossRef]

50. Larrinaga-Gonzalez, C.; Bebbington, J. Accounting change or institutional appropriation?-A case study of the implementation of environmental accounting. Crit. Perspect. Account. 2001, 12, 269-292. [CrossRef]

51. She, C.; Michelon, G. Managing stakeholder perceptions: Organized hypocrisy in CSR disclosures on Facebook. Crit. Perspect. Account. 2019, 61, 54-76. [CrossRef]

52. Bebbington, J.; Schneider, T.; Stevenson, L.; Fox, A. Fossil fuel reserves and resources reporting and unburnable carbon: Investigating conflicting accounts. Crit. Perspect. Account. 2020, 66. [CrossRef]

53. Bebbington, J. Sustainable development: A review of the international development, business and accounting literature. Account. Forum 2001, 25, 128-157. [CrossRef]

54. Bebbington, J.; Brown, J.; Frame, B. Accounting technologies and sustainability assessment models. Ecol. Econ. 2007, 61, 224-236. [CrossRef]

55. Dumay, J.; Guthrie, J.; Farneti, F. GRI sustainability reporting guidelines for public and third sector organizations: A critical review. Public Manag. Rev. 2010, 12, 531-548. [CrossRef]

56. Ball, A.; Craig, R. Using neo-institutionalism to advance social and environmental accounting. Crit. Perspect. Account. 2010, 21, 283-293. [CrossRef]

57. Ball, A. Environmental accounting and change in UK local government. Account. Audit. Account. J. 2005, 18, 346-373. [CrossRef]

58. Xing, Y.; Horner REl-Haram, M.; Bebbington, J. A framework model for assessing sustainability impacts of urban development. Account. Forum 2009, 33, 209-224. [CrossRef]

59. O'Dwyer, B. Stakeholder democracy: Challenges and contributions from social accounting. Bus. Ethics Eur. Rev. 2005, 14. [CrossRef] 
60. Birkin, F.; Polesie, T.; Lewis, L. A new business model for sustainable development: An exploratory study using the theory of constraints in Nordic organizations. Bus. Strategy Environ. 2009, 18, 277-290. [CrossRef]

61. Birkin, F.; Cashman, A.; Koh, S. New sustainable business models in China. Bus. Strategy Environ. 2009, 18, 64-77. [CrossRef]

62. Everett, J. Exploring (false) dualisms for environmental accounting praxis. Crit. Perspect. Account. 2004, 15, 1061-1084. [CrossRef]

63. Feger, C.; Mermet, L. A blueprint towards accounting for the management of ecosystems. Account. Audit. Account. J. 2017, 30, 1511-1536. [CrossRef]

64. Zhou, Z.; Ou, J.; Li, S. Ecological accounting: A research review and conceptual framework. J. Environ. Prot. 2016, 7. [CrossRef]

65. Gibassier, D.; Alcouffe, S. Environmental management accounting: The missing link to sustainability? (Editorial). Soc. Environ. Account. J. 2018, 38,1-18. [CrossRef]

66. Gomez-Conde, J.; Lunkes, R.; Rosa, F. Environmental innovation practices and operational performance. Account. Audit. Account. J. 2019. [CrossRef]

67. Wang, S.; Wang, H.; Wang, J. Exploring the effects of institutional pressures on the implementation of environmental management accounting: Do top management support and perceived benefit work? Strategy Environ. 2019, 28, 233-243. [CrossRef]

68. Johnstone, L. Theorising and conceptualising the sustainability control system for effective sustainability management. J. Manag. Control 2019, 30, 25-64. [CrossRef]

69. Christine, D.; Yadiati, W.; Afiah, N. The relationship of environmental management accounting, environmental strategy and managerial commitment with environmental performance and economic performance. Int. J. Energy Econ. Policy 2019, 9, 458-464. [CrossRef]

70. Laasch, O.; Moosmayer, D.; Antonacopoulou, E. Constellations of transdisciplinary practices: A map and research agenda for the responsible management learning field. J. Bus. Ethics 2020, 162, 735-757. [CrossRef]

Publisher's Note: MDPI stays neutral with regard to jurisdictional claims in published maps and institutional affiliations.

(C) 2020 by the author. Licensee MDPI, Basel, Switzerland. This article is an open access article distributed under the terms and conditions of the Creative Commons Attribution (CC BY) license (http://creativecommons.org/licenses/by/4.0/). 